\title{
Blood Donor
}

National Cancer Institute

\section{Source}

National Cancer Institute. Blood Donor. NCI Thesaurus. Code C132448.

Someone from whom blood is removed for transplantation or other purpose. 